\title{
Strategi Lembaga Bantuan Hukum dalam Menangani Perkara Perdata di LKBHI IAIN Salatiga
}

\author{
Nurrun Jamaludin \\ Institut Agama Islam Negeri (IAIN) Salatiga \\ Nurrunjamaludin@iainsalatiga.ac.id
}

\begin{abstract}
This research try to find out the strategy of handling case civil case at the Islamic Legal Consultation and Assistance Institute of IAIN Salatiga, nowadays many Legal Aid Institute just focus on litigation process to get money from the Ministry of Justice and Human Rights, but the main function of Legal aid Institute are neglected such as legal studies and legal counseling, besides forgetting the legal function as the aspire of the law, that is to be social control and civil engineer. This research/study using evaluative analysis method, the method is collecting and presenting all LKBHI data since 2016-2018 then analyze the actual facts and then analyze them rationally based on juridical principles through library research and on the spot research.The finding of this research indicate that LKBHI IAIN Salatiga has finished many civil case, but many solution using non litigation process, when the strategy built to resolve cases using a psychological approach to the parties, while also applying procedures to the team to resolve client's case with negotiation and mediation, where all participants on the team is active and doing the work based on their own expertise. Then the results lead by LKBHI IAIN Salatiga the solution is a win-win solution are quite significant.
\end{abstract}

Keyword: Strategy, legal aid institution, civil case

\begin{abstract}
Abstrak
Penelitian ini bertujuan untuk mengetahui strategi penanganan perkara perdata di Lembaga Konsultasi dan Bantuan Hukum Islam IAIN Salatiga, secara umum lembaga bantuan hukum hari ini masih banyak terfokus pada proses litigasi dengan tujuan untuk mengakses dana dari Kementerian Hukum dan Ham namun fungsi dasar dari lembaga bantuan hukum banyak yang terabaikan, seperti kajian hukum dan penyuluhan hukum, selain itu juga melupakan atas fungsi hukum sebagaimana yang di cita cita kan oleh hukum sendiri yaitu menjadi sarana control sosial dan rekayasa masyarakat. Penelitian ini menggunakan pendekatan evaluatif analisis yaitu metode dengan mengumpulkan dan menyajikan suluruh data LKBHI Mulai tahun 2016-2018 untuk kemudian di analisis fakta yang sebenarnya dan selanjutnya dianalisis secara rasional berdasarkan prinsip yuridis melalui penelitian kepustakaan dan penelitian lapangan. Temuan
\end{abstract}

Al-Istinbath : Jurnal Hukum Islam Vol. 4, No. 1, 2019; 15-34 p-issn: 2548-3374; e-issn: 2548-3382, DOI: 10.29240/jhi.v4i1.709

Available online at: http://journal.staincurup.ac.id/index.php/alistinbath 
penelitian ini menunjukan bahwa LKBHI IAIN Salatiga telah banyak menyelesaikan perkara perdata, namun penyelesaiannya lebih banyak menggunakan proses non litigasi, dimana strategi yang dibangun untuk menyelesaikan perkara menggunakan pendekatan psikologi terhadap para pihak, selain itu juga menerapkan prosedur kepada tim untuk menyelesaikan perkara klien dengan cara negosiasi dan mediasi, yaitu tim terlibat aktif didalamnya dengan pembagian tim sesuai dengan keahliannya, sehingga hasil yang dituai oleh LKBHI IAIN Salatiga dalam penyelesaian yang bersifat win win solution cukup signifikan.

Kata kunci: Strategi, lembaga bantuan hukum, perkara perdata

\section{Pendahuluan}

Permasalahan hukum terjadi karena beberapa hal, antara lain diakibatkan oleh lemahnya sistem peradilannya, buruknya mentalitas penegak hukum, intervensi kekuasaan, maupun produk hukum yang i-relevan, kondisi tersebut diperburuk dengan rendahnya kesadaran hukum masyarakat sehingga tidak paham terhadap aturan aturan yang ada, seperti ketika ada undang-undang bantuan hukum tahun 2011 masyarakat tidak semua tau adanya bantuan hukum diberikan kepada orang miskin dalam menjamin keadilan hak nya, namun di sisi lain masyarakat menuntut akan keadilan dihadapan hukum. ${ }^{1}$

Salah satu kelompok hukum yang tidak bisa dipisahkan dari kehidupan masyarakat adalah hukum perdata yaitu segala aturan hukum yang mengatur hubungan hukum antara orang yang satu dengan orang lain dalam hidup bermasyarakat, hubungan hukum tersebut dapat terjadi karena, perjajian antara pihak satu dengan pihak lain, ketentuan undang-undang yang bermanfaat atau saling menguntungkan bagi pihak-pihak, atau ketentuan undang-undang yang merugikan orang lain misalnya perbuatan melawan hukum, maka dapat disimpukan sebagai akibat berikutnya hukum perdata adalah pelaksanaan dan pemenuhan realisasi kewajiban diantaranya: Pertama apabila kedua belah pihak memenuhi kewajiban dan hak timbal balik secara penuh, Kedua apabila salah satu pihak tidak memenuhi kewajibannya, dan Ketiga apabila kerugian akibat perbuatan melawan hukum (onrechtmatige daad). ${ }^{2}$

Proses penegakan hukum perdata dewasa ini selain penyelesaiannya membutuhkan waktu cukup lama bahkan dalam biaya perkara pun relatif tinggi sebagaimana ketentuan Pasal 2 Perma No. 3 Tahun 2012. ${ }^{3}$ Semua itu belum termasuk biaya untuk menyewa jasa pengacara hingga pemeriksaan perkara. karena komponen biaya tersebut memiliki kontribusi paling besar atau pengaruh

${ }^{1}$ Morris Ginsberg, Keadilan Dalam Masyarakat, (Bantul: Pondok Edukasi, 2003), h. 41.

2 Abdul Kadir Muhammad, Hukum Perdata Indonesia, (Bandung: PT Citra Aditya Abadi, 2014), h. 22.

${ }^{3}$ Lihat Perma No. 3 tahun 2012 tentang biaya proses penyelesaian perkara dan pengelolaannya pada Mahkamah Agung dan badan peradilan yang ada di bawahnya. 
terhadap kualitas penyelesaian sengketa perkara perdata, selain itu pengumpulan bukti-bukti yang tersebar di seluruh Indonesia, pengacara juga harus travelling, mendatangkan saksi, hingga menemukan bukti dan dokumen yang lama hingga uji lab untuk suatu perkara tertentu, kendati demikian, peradilan masih dijadikan "the First and the last resort" dalam menyelesaikan sengketa, seolah-olah manusia terperdaya, hanya badan peradilan yang dianggap mampu memberi penyelesaian yang adil. ${ }^{4}$

Lembaga bantuan hukum lahir karena adanya suatu harapan baru dalam membantu masyarakat berhadapan dengan hukum yang tidak mampu baik secara ekonomi maupun kedudukan strata sosial serta minimnya pengetahuan hukum mereka, selain itu terdorong karena keinginan dalam mewujudkan supremasi hukum bagi seluruh warga Negara, keberadaannya pun sangat penting ditengah-tengah masyarakat mengigat prinsip persamaan di depan hukum. ${ }^{5}$ Cita bantuan hukum tidak lain adalah supremasi hukum, namun perlu kiranya membedaakan antara bantuan hukum yang diberikan oleh kentor advokat dan lembaga bantuan hukum, karena jelas dalam undang-undang no 16 tahun 2011 lembaga bantuan hukum bersifat non profit padahal dapat kita jumpai lembaga bantuan hukum yang menyampaikan peran lembaganya salah satunya adalam membuka lapangan kerja, padahal seharusnya orang yang masuk dalam lembaga bantuan hukum tidak lah semata mengejar materi namun lebih pada dedikasi (pengabdian) kepada bangsa dan Negara untuk menjadi bagian dari penegak hukum dalam menjamin hukum yang berkeadilan. ${ }^{6}$

Banyak lembaga bantuan hukum hari ini guna eksistensi lembaganya mereka berbondong-bondong untuk mengakses dana yang diberikan pemerintah dalam menyelesaikan sengketa dengan cara mendaftarkan akreditasi lembaga bantuan hukum mereka kepada Kementerian hukum dan HAM, namun ironinya karena antusiasme terhadap penanagan perkara litigasi yang sangat tinggi dan notabene setiap perkara bisa di klaim kan ke APBN melalui kemenkumham menjadikan mereka melupakan tugas dan cita-cita lembaga bantuan hukum, sehingga tidak heran jika banyak lembaga bantuan hukum yang belum terakreditasi tidak banyak berperan terhadap bantuan hukum masyarakat khususnya orang miskin, padahal dasar lembaga bantuan hukum adalah sebagai lembaga social non profit yang mengedepankan prinsip prinsip keadilan, ironinya justru ada temuan oleh panitia verifikasi dan akreditasi OBH periode 2019-2021 dimana banyak lembaga bantuan hukum menghalalkan segala cara diantaranya memanipulasi data yang dilakukan oleh advokat dan lembaga

\footnotetext{
${ }^{4}$ Rahmadi Usman, Pilihan Penyelesaian Sengketa di Luar Pengadilan, h. 14.

5 T.Mulya Lubis, Bantuan Hukum dan Kemiskinan Struktural, (Jakarta: LP3ES, 1986), h. 15.

${ }^{6}$ Hariyanto, Peran LBH Kampus Di PTKIN Dalam Bantuan Hukum Terbadap Masyarakat Miskin, Jurnal Al-'Adl, Vol. 10 No. 1, Januari 2017
} 
bantuan hukum kampus supaya mereka bisa lolos seleksi akreditasi bantuan hukum dan mendapatkan dana dari pemerintah guna eksistensi lembaganya. ${ }^{7}$

Banyak juga organisasi bantuan hukum yang masih terfokus pada pembahasan tentang kriteria surat keterangan miskin (SKTM) apakah indikatornya miskin tidak mampu secara ekonomi atau miskin pengetahuan, dengan anggapan bahwa jika SKTM tidak ada kriteria yang jelas maka akan banyak penyalah gunaan dan juga menghambat proses reimbursement. Meskipun sudah ada anggaran sebesar 5.000.000 (lima Juta) untuk 1 perkara litigasi itu masih dirasa kurang dengan alasan banyak pengeluaran perkara mulai dari kepolisian jika pidana dan mulai dari gugatan jika perdata. ${ }^{8}$

Penulis dalam penelitian ini menggunakan metode evaluatif analisis ${ }^{9}$ yaitu akan fokus pada satu Lembaga Konsultasi dan Bantuan Hukum Islam (LKBHI) IAIN Salatiga yang notabene belum terakreditasi dan belum bisa mengakses dana APBN Melalui BPHN namun bisa menyelesaikan banyak perkara yang diantaranya warga Negara tidak mampu sehingga menjadi sangat penting kiranya mengetahui strategi apa yang di pakai oleh LKBHI dalam penyelesaian perkara perdata dan sejauh mana peran LKBHI dalam penanganan perkara perdata, kemudian bagaimana cara LKBHI IAIN Salatiga menjaga eksistensi lembaga sehingga sampai sekarang masih berkomitmen menjadi wadah pengabdian terhadap masyarakat. diawali ejak tahun 2002 unit Lembaga Konsultasi dan Bantuan Hukum Islam (LKBHI) IAIN Salatiga dibentuk dan telah menyelesaikan berbagai Perkara baik yang diselesaiakan melalui proses litigasi maupun non litigasi, namun pada penelitian ini hanya akan mengkaji data penanganan perkara LKBHI IAIN Salatiga pada periode 2016-2018.

\section{Pembahasan}

Dewasa ini hukum dapat kita tafsirkan sebagai suatu kebutuhan primer dalam kehidupan sosial masyarakat, yaitu hukum akan melayani warga masyarakat, mulai dari pengalokasian kekuasaan, pendistribusian sumber daya, serta perlingungan atas kepentingan anggota masyarakat itu sendiri, oleh karenanya hukum menjadi sangat penting peranannya sebagai sarana untuk mewujudkan kebijaksanaan pemerintah. Kesadaran yang menjadikan bahwa hukum termasuk instrumen penting untuk mewujudkan tujuan-tujuan tertentu, menjadikan hukum sebagai sarana yang aktif digunakan untuk mengatur

${ }^{7}$ BPHN, Ada Advokat dan Kampus Palsukan Data Demi Dana Bantuan Hukum. https://www.hukumonline.com, di akses 11 Januari 2019.

8 Yusuf Saifudin, (2015), Implementasi Pemberian Bantuah Hukum bagi Rakyat Miskin di Jawa Tengah berdasarkan undang-undang nomor 16 tabun 2011 Tentang Bantuan Hukum, Jurnal Idea Hukum, Vol.1 Edisi Maret 2015.

${ }^{9}$ Soerjono Soekanto, Pengantar Penelitian Hukum, (Jakarta: UI Press, 1984), h. 5. 
masyarakat, melalui penggunaan peraturan hukum yang dibuat dengan sengaja, ${ }^{10}$ karena mengingat fungsi hukum dalam masyarakat selain sebagai sarana penyelesaian konflik (conflict settlement), juga sebagaisarana kontrol sosial, sebagai sarana rekayasa sosial, sarana pengintegrasi sosial, dan terakhir sebagai sarana pemberdayaan sosial yang bersifat humanis partisipatoris. ${ }^{11}$

Hukum akan berubah bersama perubahan masyarakat, baik perubahan hukum secara tertulis muapun yang tidak tertulis, perubahan tersebut juga terletak pada cara menafsirkan peraturan perundang-undangan umpamanya perubahan konsep masyarakat industri modern tentang hak milik, perubahan pembatasan hak milik yang bersifat publik, peralihan tanggung jawab dari tuntutan ganti rugi menjadi asuransi, perubahan dalam jangkauan lingkup hubungan internasional dan perubahan-perubahan lain, sehingga cukup penting kiranya mengevaluasi dengan mengumpulkan data kemudian dianalisis fakta secara rasional berdasarkan prinsip yuridis bisa menemukan idealisme penanganan hukum yang berkeadilan. ${ }^{12}$

Dasar dari setiap sistem hukum menunjukkan empat unsur yaitu: pranata peraturan perundang-undangan, proses penyelenggaraan hukum, prosedur penyampaian keputusan oleh pengadilan dan lembaga penegakan hukum, sehingga pendekatan pengembangan terhadap sistem hukum menekankan pada beberapa hal yaitu: meningkatnya diferensiasi internal dari keempat unsur dasar sistem hukum tersebut, termasuk perangkat peraturan, aplikasi peraturan, pengadilan dan aparat penegakan hukum serta pengaruh diferensiasi lembaga dalam masyarakat terhadap unsur-unsur dasar tersebut. ${ }^{13}$

Standar penyelesaian terhadap perkara pun dituntut untuk melakukan perubahan sesuai kebutuhan dan permasalahannya, karena cara penyelesaian sengketa akan sangat menentukan solusi dan dampak atas keberlangsungan kehidupan para pihak, dalam istilah penyelesaian sengketa perdata ada dua istilah pokok yaitu proses penanganan perkara secara litigasi dan non litigasi.

Pemberian bantuan hukum sebagaimana fungsi dan peran lembaga bantuan hukum dalam rangka melakukan pendampingan, pendidikan hukum dan kajian hukum bagi masyarakat yang mengalami masalah hukum baik litigasi maupun non litigasi tentu tidak lepas dari pemahaman pengertian tentang bantuan hukum itu sendiri dan tentang jasa advokat dan pemerhati hukum seperti kaum akademisi dan masyarakat yang peduli atas pemberian bantuan

${ }^{10}$ Satjipto Rahardjo, Hukum dalam Perspektif Sejarah dan Perubahan Sosial dalam Pembangunan Hukum dalam Perspektif Politik. Hukum Nasional, (Jakarta: Rajawali Press, 1996), 19.

${ }^{11}$ Rahmadi Usman, Pilihan Penyelesaian sengketa di Luar Pengadilan, h. 1.

${ }^{12}$ Soerjono Soekanto, Pengantar Penelitian Hukum, (Jakarta: UI Press, 1984), h. 5.

13 Mardjono Reksodiputro. Sistem Peradilan Pidana Indonesia Melibat Kejabatan dan Penegakan Hukum dalam Batas-Batas Toleransi). (Jakarta: Pusat Keadilan dan Pengabdian Hukum, 1994), h. 79. 
hukum, walaupun kecenderungan advokat sebagaisentral dalam pemberian advokasi di pengadilan maupun di luar pengadilan dalam perkara perdata. Berikut adalah pengertian tentang bantuan hukum, yaitu :

1. Tertuang dalam Undang-Undang No.18 Tahun 2003 Tentang advokat pasal 1 angka 9 "Bantuan Hukum adalah Jasa hukum yang diberikan oleh advokat secara cuma-cuma kepada klien yang tidak mampu". ${ }^{14}$

2. Tertuang dalam undang-undang No.16 Tahun 2011 Tentang Bantuan Hukum pasal 1 angka 1 yaitu "Bantuan Hukum adalah jasa hukum yang diberikan oleh pemberi bantuan hukum secara cuma-cuma kepada penerima bantuan hukum". ${ }^{15}$

3. Tertuang dalam permenkumham No. 1 Tahun 2018 Tentang Paralegal dalam Pemberian Bantuan Hukum pasal 1 "Bantuan Hukum adalah jasa hukum yang diberikan oleh pemberi bantuan hukum secara cuma-cuma kepada Penerima Bantuan Hukum". ${ }^{16}$

4. Pelaksanaan pemberian bantuan hukum terdiri dari legal aid dan legal assistance, istilah legal aid diartikan sebagai pemberian bantuan hukum cuma-cuma kepada masyarakat yang tidak mampu sedangkan legal asistance yaitu bantuan hukum secara cuma-cuma dan pendampingan yang mengunakan jasa honorarium sebagai jasa hukumnya. ${ }^{17}$

Berdasarkan pengertian di atas maka secara prinsip bantuan hukum merupakan proses pemberian jasa hukum yang dilakukan oleh advokat, pengacara atau pemberi bantuan hukum kepada masyarakat yang tidak mampu atau miskin secara cuma-cuma supaya mereka dapat memperjuangkan hak-hak hukumnya selama menjalani proses penanganan perkara baik pemeriksaan di pengadilan maupun diluar pengadilan. Istilah lain dari bantuan hukum yang banyak dipahami oleh masyarakat adalah advokasi yang dalam pengertianya adalah kegiatan-kegiatan yang menyangkut aktivitas mempengaruhi penguasa atau lembaga lembaga menyangkut masalah yang sedang dialami oleh rakyat kecil atau rakyat tidak mampu dan miskin, terutama terhadap mereka yang dikucilkan atau dipingirkan dari proses politik, ekonomi dan sosial. ${ }^{18}$

Berdasarkan penjelasan di atas antara advokasi dan bantuan hukum memilki kesamaan yaitu pemberian jasa hukum terhadap masyarakat tidak mampu baik secara hukum maupun politik, ekonomi dan sosial, tujuan pemberian bantuan hukum adalah terciptanya keadilan yang merata dan adanya

${ }^{14}$ UU No.18 Tahun 2003 pasal 1 angka 9 Tentang Advokat

${ }^{15}$ UU No.16 Tahun 2011 pasal 1 angka 1Tentang Bantuan Hukum

${ }_{16}$ Permenkumham RI No.1 Tahun 2018 pasal 1 tentang Paralegal Dalam Pemberian Bantuan Hukum.

${ }^{17}$ Yahya Harahap, Pembahasan dan Penerapan KUHAP: Penyidikan dan Penuntutan, (Jakarta, Sinar Grafika, 2009), h. 334.

18 Valerie Miller dan Jane Copey, Pedoman Advokasi: Kerangka kerja Untuk Perencanaan, Tindakan dan Refleksi, (Jakarta: Yayasan Obor Indonesia, 2005), h. 12. 
perlindungan hukum dan hak asasi bagi warganegara khusunya yang tidak mampu, persamaan tersebut dapat diuraikan sebagai berikut:

1. Bantuan hukum itu merupakan suatu hak, ini berarti bahwa subyek hukum berhak mendapatkan bantuan hukum bila ia memerlukanya.

2. Bantuan hukum itu merupakan suatu pekerjaan yang profesional yang dilakukan oleh orang tertentu berdasarkan syarat-syarat tertentu.

3. Bantuan hukum itu merupakan pemberian jasa kepada orang yang memerlukanya yg dilakukan oleh orang tertentu.

4. Bantuan hukum itu diberikan untuk semua aspek kehidupan. ${ }^{19}$

Lembaga bantuan hukum juga mempunyai tugas sesuai tujuan diadakannya program bantuan hukum yaitu berkaitan dengan beberapa aspek seperti:

1. Aspek Kemanusiaan

Tujuan dari program bantuan hukum ini tak lain adalah untuk meringankan beban (biaya) perkara yang harus di tanggung oleh masyarakat miskin di pengadilan dan diluar pengadilan, dengan demikian ketika masyarakat miskin berhadapan dengan hukum mereka tetap akan memperoleh kesempatan untuk memperoleh pembelaan dan perlindungan hukum.

2. Peningkatan Kesadaran Hukum

Tujuan aspek kesadaran hukum, dimana tingginya kesadaran hukum kearah yang lebih baik adalah perwujudan dari harapan program bantuan hukum ini dibuat, dengan demikian, apresiasi masyarakat terhadap hukum akan tampil melalui sikap dan perbuatan yang mencerminkan hak dan kewajiban secara hukum. ${ }^{20}$

Pada prinsipnya bantuan hukum dapat dilaksanakan oleh advokat berdasarkan UU Advokat, dapat juga dilakukan oleh pemberi bantuan hukum berdasarkan UU bantuan hukum yaitu seorang legal assistant yang tugasnya membantu seorang legal dalam pemberian, perbuatan atau saran-saran hukum kepada masyarakat dan langsung bertanggung jawab kepada seorang legal, memiliki pengetahuan dan keterampilan di bidang hukum, telah mengikuti pendidikan khusus keparalegalan dan dilakukan supervisi oleh advokat atau badan hukum lainnya, walaupun pelaksanaan pemberi bantuan hukum tidak sepenuhnya dapat diberikan oleh selain advokat karena terbatas dengan peraturan perundang-undangan, meskipun pemberian bantuan hukum saat ini belum menjangkau seluruh masyarakat Indonesia karena adanya keterbatasan pelaksana bantuan hukum sehingga sebenarnya peran dari paralegal sebagai

h. 22 .

${ }_{19}$ Abdurahman, Aspek-aspek Bantuan Hukum di Indonesia, (Jakarta: Cendana Press, 1983),

${ }^{20}$ Adnan Buyung Nasution, Bantuan Hukum di Indonesia, (Jakarta : LP3ES, 1988), h. 6-7. 
pemberi bantuan hukum untuk meningkatkan jangkauan pemberian bantuan hukum sangat dibutuhkan khususnya dalam pemberian bantuan hukum guna menyelesaikan sengketa perdata di masyarakat luas.

Negara menjamin pemberian akses bantuan hukum dalam berbagai undang-undang dan peraturan yang berkaitan dengan akses masyarakat terhadap hukum dan keadilan. Pengadilan juga mempunyai asas aktif memberi bantuan dan asas ini dicantumkan dalam ketentuan Pasal 68 huruf B Undang-Undang Republik Indonesia Nomor 49 tahun 2009 tentang perubahan kedua atas Undang-Undang Republik Indonesia Nomor 2 tahun 1986 tentang Peradilan Umum, dalam ayat 1 berbunyi "Setiap orang yang tersangkut perkara berhak memperoleh bantuan hukum dan ayat (2) berbunyi "Negara menanggung biaya perkara bagi pencari keadilan yang tidak mampu".

Mahkamah Agung Republik Indonesia juga telah menerbitkan Peraturan Mahkamah Agung Republik Indonesia (Perma) Nomor 1 tahun 2014 tentang pedoman pemberian layanan hukum bagi masyarakat tidak mampu di pengadilan secara prodeo (cuma-cuma). Peraturan Mahkamah Agung Republik Indonesia (Perma) ini adalah tindak lanjut dari ketentuan Peraturan Pemerintah Republik Indonesia Nomor 42 Tahun 2013 tentang syarat dan tata cara pemberian bantuan hukum dan penyaluran bantuan hukum dan surat keputusan Menteri Hukum dan Hak Asasi Manusia Republik Indonesia Nomor : M.HH03.HN.03.03 tahun 2013 tentang Besaran Biaya Bantuan Hukum Litigasi dan Non-Litigasi.

Dengan terbitnya peraturan tersebut sejak tanggal diundangkan 16 Januari 2014 maka Surat Edaran Mahkamah Agung Republik Indonesia (SEMA RI) Nomor 10 tahun 2010 tentang pedoman pemberian bantuan hukum di pengadilan dinyatakan sudah tidak berlaku. Peraturan Mahkamah Agung Republik Indonesia (Perma) Nomor 1 tahun 2014 mengikat keluar khususnya bagi kalangan dunia advokat. Selain itu, dalam praktik selama ini diadakan nota kesepahaman (memorandum of understanding) antara pengadilan dengan organisasi advokat atau Lembaga Bantuan Hukum.

Hal tersebut diatas berarti negera telah memberikan perlindungan terhadap masyarakat tidak mampu dengan diberikannya jasa hukum cuma cuma dengan mekanisme yang telah ditentukan. Adapun baiaya yang akan dikeluarkan oleh penasehat hukum tersebut dalam sejarahnya pertama melalui Mahkamah Agung RI dan dalam perkembanganya sejak adanya Undang-undang RI No.16 Tahun 2011 Tentang Bantuan hukum menjadi kewenangan Kementrian Hukum dan HAM RI meskipun memang proses pembiayaanya hanya diberikan kepada organisasi bantuan hukum yang sudah terakreditasi berdasarkan Undang-undang tersebut.

Pemberian bantuan hukum oleh lembaga bantuan hukum sebagaimana diatur dalam undang-undang bantuan hukum No.16 Tahun 2011 dalam pasal 1 
memberikan pengertian sebagai berikut: bahwa bantuan hukum adalah jasa hukum yang diberikan oleh pemberi bantuan hukum secara cuma cuma kepada penerima bantuan hukum, penerima bantuan hukum adalah orang atau kelompok orang miskin, sedangkan pemberi bantuan hukum adalah lembaga bantuan hukum atau organisasi kemasyarakatan yang memberi layanan bantuan hukum berdasarkan undang-undang bantuan hukum, standar bantuan hukum adalah pedoman pelaksanaan pemberi bantuan hukum yang ditetapkan oleh menteri. ${ }^{21}$ Sasaran bantuan hukum juga mengarah pada masarakat miskin yang tidak mampu membayar jasa pengacara, dalam penelitian Yonna Beatrix Salamor diterangkan bahwa "dengan tingkat kemiskinan yang tinggi menyebabkan angka kriminal yang tinggi juga" sehingga dengan adanya undangundang bantuan hukum bisa membantu masyarakat miskin untuk menyelesaikan perkara hukumnya dengan mengedepankan prinsip keadilan. ${ }^{22}$

Terdapat dalam pasal lain tentang ruang lingkup pemberian bantuan hukum yaitu: bantuan hukum diberikan kepada penerima bantuan hukum yang menghadapi masalah hukum, bantuan hukum sebagaimana dimaksud meliputi masalah keperdataan, tata usaha Negara, pidana dan perkara non litigasi serta menjalankan kuasa untuk mendampingi, mewakili, membela atau melakukan tindakan hukum lain untuk kepentingan hukum penerima bantuan hukum. ${ }^{23}$

Sedangkan dalam definisi lain ketentuan mengenai kewenangan negara dalam hal ini dilaksanakan oleh menteri hukum dan HAM RI yaitu: Bantuan hukum diselenggarakan untuk membantu penyelesaian permasalahan hukum yang dihadapi penerima bantuan hukum. Pendampingan perkara perdata yang dilakukan oleh lembaga bantuan hukum ataupun advokat sangatlah penting fungsi dan peranya selain memang diatur dalam Kitab Undang-undang Hukum Acara Perdata juga diatur oleh undang-undang advokat dan undang-undang bantuan hukum, tentu tujuannya adalah adanya perlindungan hukum terhadap para pihak atau masyarakat yang tidak mampu untuk mendapatkan jasa advokat, karena untuk membayar honorarium advokat juga tidak murah, maka dengan adanya pendampingan dari lembaga bantuan hukum termasuk Lembaga Konsultasi dan Bantuan Hukum Islam (LKBHI) IAIN Salatiga menjadi penting fungsi dan peranya dalam menegakan hukum sebagaimna fungsinya yaitu mengatur dan menyelenggarakan kehidupan masyarakat agar dapat tercipta dan terpeliharanaya ketertiban umum.Proses pemeberian bantuan hukum oleh lembaga bantuan hukum baik dipengadilan atau diluar pengadilan harus sesuai dengan syarat-syarat yang telah ditetapkan oleh UU bantuan hukum dan aturan lainya karena hal tersebut sangart penting dalam eksistensinya memberikan

\footnotetext{
21 Pasal 1 Undang-undang No.16 Tahun 2011 tentang Bantuan Hukum

22 Yonna Beatrix Salamor, Pemberian Bantuan Hukum Kepada Masyarakat Miskin di Kota Ambon, Vol. 2, No. 1, April 2018

${ }^{23}$ pasal 4 Undang-undang No.16 Tahun 2011 tentang Bantuan Hukum
} 
pendampingan yang maksimal terhadap masyarakat agar apa yang menjadi hakhak mereka dapat terpenuhi.

Dalam perkembangannya lembaga bantuan hukum terbagi dalam dua kelompok yaitu:

1. Lembaga Bantuan Hukum Swasta

Lembaga tersebut yang telah muncul dan berkembang akhir-akhir ini, umumnya anggota dari lembaga bantuan hukum tersebut terdiri dari beberapa orang yang bergerak dalam profesi hukum Advokat, konsep dan peranannya sangat luas tidak hanya sekedar memberi bantuan hukum di depan sidang Pengadilan terhadap rakyat kecil yang miskin dan buta hukum namun lebih dari itu. Konsep dan programnya diantaranya:

a. Memprioritaskan bantuan dan nasihat hukum terhadap lapisan masyarakat kecil yang tidak mampu.

b. Memberi nasihat hukum di luar pengadilan terhadap buruh,tani, nelayan, pegawai negeri dan yang lainnya dimana mereka merasa haknya diciderai oleh orang lain ataupun Negara.

c. Mendampingi atau mewakili secara langsung di sidang pengadilan baik yang meliputi perkara perdata atau pidana.

d. Bantuan dan nasihat hukum yang mereka berikan dilakukan secara cuma-cuma untuk orang miskin.

2. Lembaga Bantuan Hukum yang Bernaung di Perguruan Tinggi

Lembaga ini sering dikenal dengan nama biro bantuan hukum, lembaga inipun hampir sama dengan lembaga bantuan hukum swasta, tetapi lembaga ini kurang populer dan mengalami kemunduran, karena munculnya UU 18 tahun 2003 yang didalamnya ada penegasan bahwa yang dapat mendampingi masyarakat untuk menyelesaikan perkaranya hanya advokat, namun dengan hadirnya UU No.16 Tahun 2011 membangkitkan semangat lembaga bantuan hukum kampus yang mulanya sedikit kendor karena keterbatasan peran oleh regulasi perundang-undnagan. ${ }^{24}$ Hamper setiap fakultas hukum hari ini memiliki lembaga bantuan hukum, selain sebagai sara pengabdian oleh dosen kepada masyarakat yang sifatnya preventif juga sebagai sarana membantu menyelesaikan permasalahan hukum yang ada pada masyarakat, baik berupa proses litigasi maupun non litigasi.

\section{Eksistensi Lembaga Konsultasi dan Bantuan Hukum Islam (LKBHI) IAIN Salatiga}

Melaksanakan tri darma perguruan tinggi merupakan tanggung jawab utama dari setiap derap kerja yang dimiliki, salah satunya adalah memberikan kontribusi yang nyata terhadap kondisi masyarakat sekitar, baik dalam skala

${ }^{24}$ Frans Hendra Winarta, Bantuan Hukum: Suatu Hak. Asasi Manusia Bukan Belas Kasiban,(Jakarta: PT Elex Media Komputindo, 2000), h. 50. 
mikro maupun makro, langsung dan tidak langsung. IAIN Salatiga dengan lembaga konsultasi dan bantuan hukum Islam (LKBHI) sebagai salah satu unit kerjanya, menjadi salah satu ujung tombak untuk program pengabdian pada masyarakat. Berkenaan dengan hal itu, pengurus LKBHI berupaya mengoptimalkan perannya untuk kepentingan masyarakat dan tanggung jawab tri darma perguruan tinggi.

Sebagai perwujudan tanggung jawab pengabdian kepada masyarakat LKBHI IAIN Salatiga selalu meningkatkan pelayanan mulai dari memberikan kajian hukum, pendidikan hukum atau nasihat hukum terhadap masyarakat sampai pendampingan dalam menyelesaikan permasalahan hukum baik melalui jalur litigasi maupun non litigasi, kepada masyarakat yang membutuhkan.

Tuntutan dinamika kehidupan masyarakrat yang meningkat, sehingga sangat perlu seluruh sumber daya manusia di LKBHI IAIN Salatiga selalu siap dan terus mengembangkan kapasitas anggotanya, supaya mampu menyelesaikan problem hukum masyarakat dengan strategi strategi yang baik secara hukum untuk masyarakat dan untuk Negara, baik secara formal mapun secara subtansi yang positif.

Subtansi penyelesaian perkara adalah dengan terciptanya keputusan win win solution, yaitu mempunyai kerangka pikir dan hati yang menitik beratkan pada tercapainya keuntungan bersama dalam setiap interaksi manusia. Win-win solution juga berarti berarti penyelesaian sengketa yang menguntungkan dan memuaskan semua pihak, dengan begitu, semua pihak merasa puas terhadap keputusan yang diterimanya.

\section{Sejarah Lembaga Konsultasi dan Bantuan Hukum Islam IAIN Salatiga}

Bantuan hukum di Indonesia dikenal sejak diberlakukannya sistem hukum barat di Indonesia, bermula pada tahun 1848 ketika di Negara Belanda terjadi perubahan besar dalam sejarah hukumnya.Berdasarkan asas konkordansi, dengan Firman Raja tertanggal 16 Mei 1848 No. 1, perundang-undangan baru di Negara Belanda tersebut juga diberlakukan di Indonesia, antara lain peraturan tentang susunan kehakiman dan kebijaksanaan peradilan (Reglement of de Regterlijke Organisaticen het beleid der Justitie), yang biasa disingkat dengan R.O. ${ }^{25}$ Peraturan tersebutlah yang dapat dijadikan perkiraan pertama kalinya lembaga advokat atau bantuan hukum secara formal mulai ada dan diaplikasikan di Indonesia. ${ }^{26}$

IAIN Salatiga sebagai satu-satunya perguruan tinggi Islam di Salatiga, memiliki cara pandang yang sama dengan nilai-nilai luhur ajaran Islam yaitu lebih berpihak pada kaum "dhu'afa", dimana fakta di wilayah Salatiga sekitarnya

${ }^{25}$ Abdurrahman, Aspek-Aspek Bantuan Hukum di Indonesia, h. 40.

${ }^{26}$ Frans Hendra Winata, Bantuan Hukum: Suatu Hak Asasi Manusia Bukan Belas Kasiban, (Jakarta: PT. Elex Media Komputindo, 2000), h. 2. 
masih banyak sekali persoalan orang tidak mampu dan belum mempunyai akses untuk mendapatkan pengetahuan hukum dan pendampingan hukum secara baik, sehingga pada tahun 2002 berinisiatif membentuk sebuah lembaga penyuluhan Konsultasi dan bantuan hukum Islam IAIN Salatiga, pada awal pendirian lembaga tersebut diketuai oleh Drs. Mahfudz, M. Ag yang saat itu sekaligus menjabat sebagai ketua Jurusan Syariah STAIN Salatiga. Pada tahun 2004 nama semula LPKBHI berubah nama menjadi LKBHI dimana direktur LKBHI pada tahun 2004-2008 dijabat oleh Evi Ariyani S.H, M.H. Pada masa kepemimpinannya ini LKBHI pernah mendampingi beberapa perkara perdata secara non litigasi, selanjutnya pada periode kepengurusan 2008-2014 LKBHI IAIN Salatiga dipimpin oleh Farkhani S.H., S.HI., M.H. dan periode 2014-2019 diprakarsai oleh M Yusuf Khummaini, SHI., MH yang telah sangat mengembangkan LKBHI secara pesat baik secara kelembagaan atau secara fungsi. LKBHI IAIN Salatiga hari ini berkedudukan hukum di Jalan nakula Sadewa Kembangarum, Kelurahan Dukuh, Kecamatan Sidomukti, Kota Salatiga.

\section{Visi dan Misi Lembaga Konsultasi dan Bantuan Hukum Islam IAIN Salatiga}

Visi:

Mewujudkan keadilan dalam masyarakat (justice for all) tanpa membeda-bedakan latar belakang agama, suku, warna kulit, jenis kelamin, dan membimbing masyarakat untuk tahu dan dapat mempertahankan hakhaknya secara hukum.

\section{Misi:}

a. Memberikan bantuan hukum kepada masyarakat baik litigasi maupun non litigasi

b. Membangun dan mengembangkan kesadaran dan kemampuan warga masyarakat dalam penyelesaian masalah-masalah hukum

c. Meningkatkan kemampuan dan keterlibatan mahasiswa, alumni, dan dosen dalam pemberian pelayanan hukum kepada warga masyarakat

d. Melakukan pengkajian, penelitian, dan pengembangan praktik hukum di masyarakat.

e. Menjalin kerjasama yang saling menguntungkan dengan lembaga pemerintah atau non pemerintah untuk pemberdayaan masyarakat di bidang hukum. 


\section{Struktur Lembaga Konsultasi dan Bantuan Hukum Islam IAIN Salatiga}

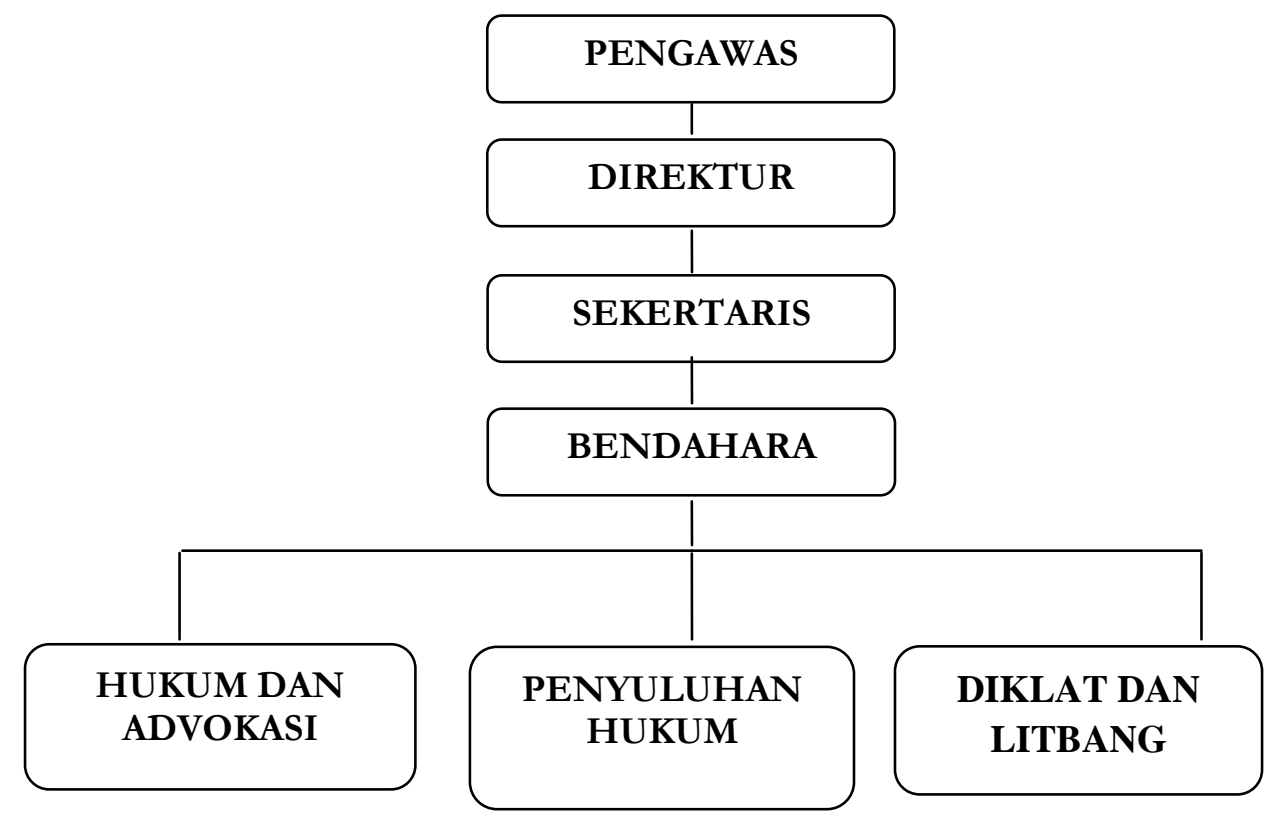

Pengawas adalah salah satu fungsi organik manajemen, dimana fungsi pengawasan sangat berguna untuk memastikan dan menjamin bahwa tujuan dan sasaran serta tugas organisasi akan dan telah terlaksana dengan baik sesuai dengan rencana, kebijaksanaan, instruksi, dan ketentuan-ketentuan yang telah ditetapkan sebelumnya. Divisi Bantuan Hukum dan advokasi diadakan untuk memberikan pelayanan di bidang bantuan hukum (baik litigasi maupun non litigasi), konsultasi hukum, pembuatan legal opinion, dan lain-lain yang dibutuhkan oleh masyarakat. Divisi Penyuluhan Dan Konsultasi Hukum diperlukan untuk memberikan pelayanan di bidang penyuluhan hukum (sosialisasi peraturan perundang-undangan) ke berbagai lapisan masyarakat, terutama di pedesaan dan ke sekolah-sekolah dalam rangka meningkatkan pengetahuan dan kesadaran hukum warga masyarakat baik dilakukan secara langsung maupun melalui brosur, media cetak, dan media elektronik serta media sosial. Divisi Diklat dan Litbang diadakan guna melakukan penelitian hukum, pembekalan dan pelatihan ketrampilan hukum, diskusi publik yang terkait dengan persoalan hukum, menjalin kerjasama dengan lembaga lain seperti Kepolisian, Pengadilan Negeri, Pengadilan Agama, Pemerintah Daerah serta lembaga lain yang menunjang pengembangan Lembaga Konsultasi dan Bantuan Hukum Islam (LKBHI) IAIN Salatiga. ${ }^{27}$ 


\section{Prosedur Pelayanan Masyarakat}

Dalam rangka menjalankan pelayanan yang professional kepada masyarakat di bidang hukum, mulai dari prosedur pemberian konsultasi hukum, pendampingan Hukum, Penyuluhan dan Pendidikan Hukum serta penelitian dan kajian hukum LKBHI menetapkan prosedur sebagai berikut;

a. Konsultasi Hukum dan Pendampingan Hukum

Klien yang datang diterima oleh bagian pendaftaran (front office) untuk di daftar dan mengisi formulir konsultasi yang disediakan. Klien dapat menulis identitas diri dan pokok persoalan hukum yang akan dikonsultasikan. Setelah itu klien diantar ke divisi hukum dan advokasi untuk ditunjukkan konsultan hukumnya sesuai dengan pokok persoalan hukum yang ditulisnya dalam blanko konsultasi.

b. Penyuluhan Hukum

Melakukan kerjasama baik dengan instansi pemerintah ataupun dengan kelompok masyarakat, kemudian melihat kebutuhan pada masing masing pihak yang sudah bekerjasama, kemudian dilakukan penyuluhan hukum dalam bentuk Focus Group Discussion (FGD) dan Seminar hukum oleh Angoota LKBHI sesuai dengan keahliannya pada bidang masingmasing.

c. Penelitian dan Kajian Hukum

Out Put dari penyuluhan hukum terhadap masyarakat langsung kemudian dilakukan kajian atas temuan masalah yang baru dan dilakukan penelitian ulang untuk menelaah permasalahan secara ilmiah demi terwujudnya solusi yang bisa menciptakan budaya hukum yang baik. ${ }^{28}$

\section{Program Kerja LKBHI IAIN Salatiga}

Sebagai lembaga yang bergerak dalam bidang bantuan hukumsalah satu kewajibannya secara umum adalah melakukan penanganan perkara Litigasi dan Non litigasi untuk dengan penuh tanggung jawab dan meberikan pelayanan yang baik secara hukum, adapun perkara litigasi dan non litigasi sebagai berikut :

a. Litigasi : adalah perkara yang masuk dalam ruang pengadilan yaitu :

1) perkara pidana

2) perdata dan

3) Tata Usaha Negara

b. Non Litigasi : adalah perkara di luar persidangan yaitu;

1) Penyuluhan hukum

2) Konsultasi hukum

3) Mediasi

4) Konsiliasi 
5) Penelitian hukum

6) Pemberdayaan masyarakat

7) Penanganan perkara diluar pengadilan

8) Drafting hukum

Data Penanganan Perkara LKBHI IAIN Salatiga tahun 2016-2018

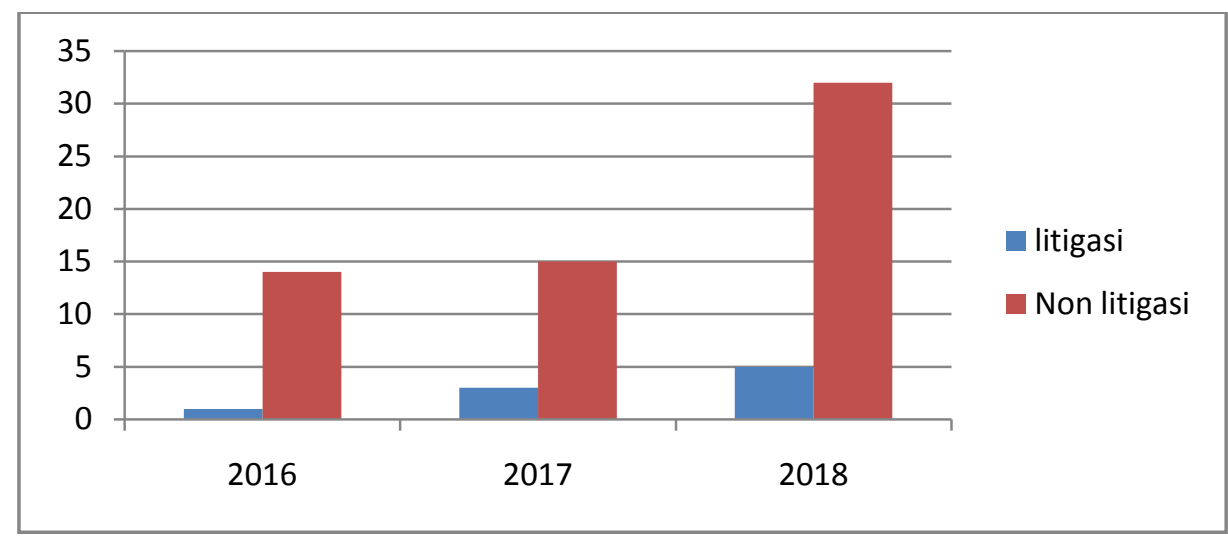

Tabel 1. Penanganan perkara litigasi dan non litigasi LKBHI IAIN Salatiga

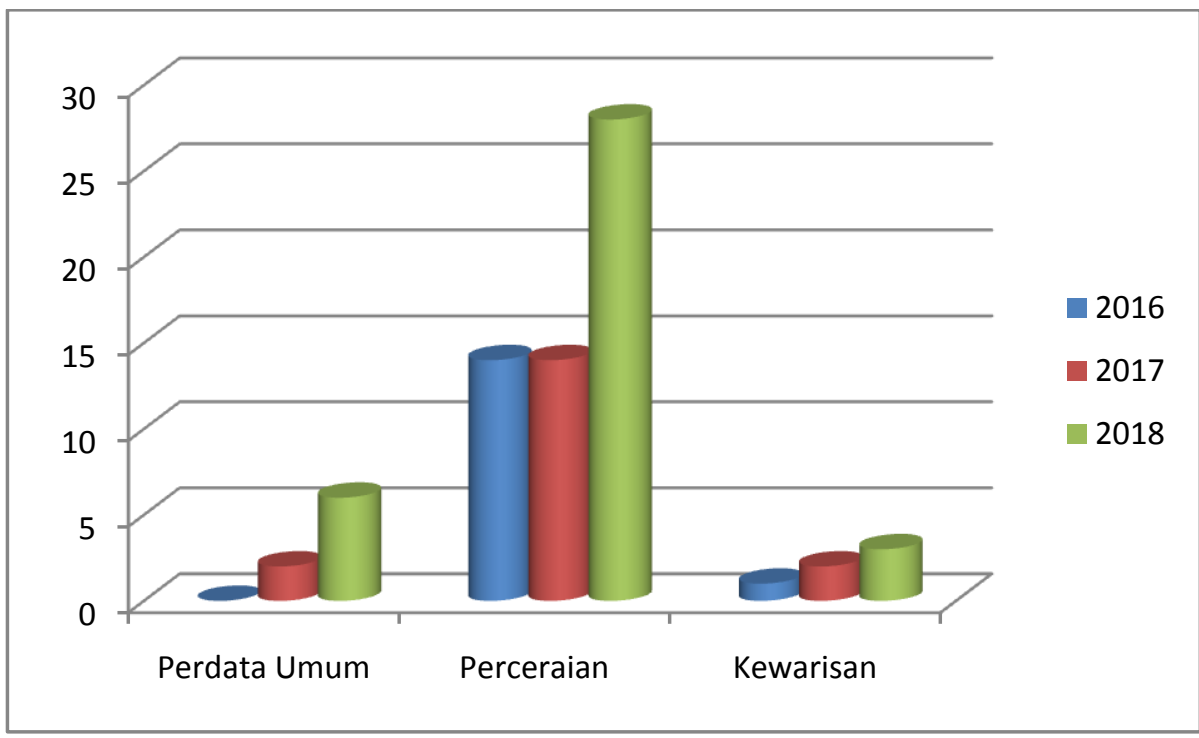

Tabel 2. Rincian Pengananan Perkara Perdata LKBHI IAIN Salatiga

Berdasarkan penjelasan tersebut diatas maka penulis hanya fokus pada Strategi penanganan perkara perdata oleh LKBHI IAIN Salatiga, oleh karenanya penejelasan nya nanti tidak banyak menguraikan tentang eksistensi dalam penanganan perkara di luar perkara Perdata, dalam melaksanakan penyelesaian sengketa perdata sesuai amanah UU Bantuan hukum yang terfokus pada subtansi penegakan hukum yang diinginkan oleh cita-cita hukum. Dari penelitian yang dilakukan melalui observasi lapangan, didapatkan data sebagai berikut yaitu: 
Penanganan perkara Litigasi dan non litigasi yang telah dilakukan mulai tahun 2016, 2017 dan 2018 dengan jumlah pada tahun 2016 sebanyak 1 litigasi dan 14 perkara non litigasi, tahun 20173 perkara litigasi dan 15 Non litigasi, tahun 2018 terdapat 5 perkara litigasi dan 32 Non litigasi. ${ }^{29}$ data tersebut memberikan gambaran Nampak jelas bahwa LKBHI IAIN Salatiga setiap tahunnya lebih banyak menyelesaikan sengketa perdata melalui proses non litigasi, padahal untuk menyelesaikan sengketa diluar persidangan tidak lah mudah, berbeda dengan lembaga bantuan hukum lain seperti di Biro Konsultasi Hukum Kartini dimana Jumlah pendampingan perkara Tahun 2016 yaitu 50 perkara diselesaikan melalui proses litigasi dan 21 diselesaikan melalui proses Non litigasi. ${ }^{30}$

\section{Strategi LKBHI dalam Penanganan Perkara Perdata}

Dinamika masalah dalam hukum perdata memaksa kita turut menyesuaikan proses penyelesaian perkara yang baik untuk para pihak, dalam hal ini LKBHI IAIN Salatiga selalu meningkatkan Metode alternatif penyelesaian sengketa sesuai amanah UUD tahun 1945, UU Hukum perdata, UU no 30 tahun 1999 tentang alternatif penyelesaian sengketa dan UU No 16 Tahun 2011 tentang bantuan hukum, dan tak lain amanah yang tertinggi dari Allah SWT yaitu:

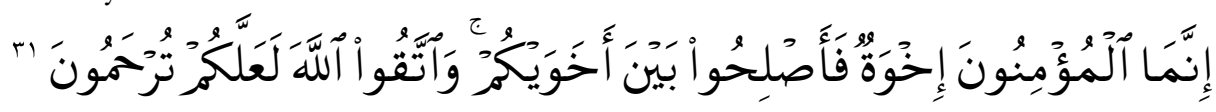

Sehingga dalam proses penyelesaian sengketa LKBHI IAIN Salatiga dengan prosedur yang digunakan dimana awal klien datang ke bagian front office untuk diberikan formulir konsultasi dan setelah terisi kemudian penujukan ahli (tim) untuk menangani perkara sesuai dengan bidangnya, kemudian dalam penyelesaian sengketa menggunakan pendekatan psikologi sebagai pendekatan personal terhadap masalah dan juga diutamakan menggunakan proses non litigasi dengan bentuk negosiasi dan mediasi dengan mekanisme sebagai berikut:

a. Negosiasi adalah metode untuk mencari penyelesaian sengketa melalui musyawarah secara langsung antara para pihak yang bersengketa yang hasilnya diterima oleh semua pihak. Jadi, negosiasi tampak sebagai suatu metode khusus untuk mencapai kesepakatan dan bukan ilmu yang dapat secara langsung dipelajari. Pada praktiknya negosiasi dilakukan karena sebagai saranapenyelesaian perselisihan atau sengketa yang timbul di antara

${ }^{29}$ Wawancara dengan direktur LKBHI M. Yusuf Khummaini, 09-Januari-2019

${ }^{30}$ Retno Sari Dewi dan Viendha Yuli Agustin, Peran Lembaga Bantuan Hukum "Kartini" Dalam Menjamin Dan Memenubi Hak Rakyat Miskin Untuk. Mendapatkan Akses Keadilan Di Dalam Proses Peradilan, Vol 3, No 1 2017. 11.

www.jurnal-unita.org/index.php/yustitia/article/download/131/123

31 “Orang-orang beriman itu Sesungguhnya bersaudara. sebab itu damaikanlah (perbaikilah hubungan) antara kedua saudaramu itu dan takutlah terhadap Allah, supaya kamu mendapat rahmat" QS. Alhujurat : 10. 
para pihak. Menurut Howard Raiffia, sebagaimana dikutip oleh Suyud Margono $^{32}$ Negosiasi ini dilakukan dengan cara LKBHI IAIN Salatiga menjadi negosiator dari klien yang datang kepada pihak lain yang ada dalam perkara tersebut kemudian mewakili bernegosiasi atas permasalahannya.

b. Mediasi adalah proses Penyelesaian sengketa di mana pihak luar yang tidak memihak (impartial) dan netral bekerja dengan pihak yang bersengketa untuk membantu mereka memperoleh kesepakatan perjanjian dengan memuaskan. Berbeda dengan hakim atau arbiter, mediator tidak mempunyai wewenang untuk memutuskan sengketa antara para pihak, namun dalam hal ini para pihak menguasakan kepada mediator untuk membantu mereka menyelesaikan persoalan-persoalan diantara mereka. ${ }^{33}$ Mediasi ini dilakukan dengan cara LKBHI IAIN Salatiga menjadi pihak ketiga dari para pihak baik klien yang pertama mengadu ke LKBHI IAIN Salatiga maupun kepada yang teradu. Dalah hal ini tim tidak memihak kepada para pihak namun berada di posisi tengah supaya keduanya mendapatkan hasil mufakat (win win solution) dengan pendekatan psikologi yang digunakan.

\section{Hambatan dan Kendala dalam Penanganan Perkara Perdata}

Sebagai lembaga konsultasi dan bantuan hukum perguruan tinggi, LKBHI IAIN Salatiga sangat ingin berperan dalam seluruh proses program bantuan hukum namun masih sedikit terdapat kendala yaitu aspek teknis dimana tempat atau domisili hukum yang kurang representatif hal tersebut karena kantor yang ada saat ini tidak terlalu dekat dengan akses jalan rasa, selain itu kantor juga tidak terlalu luas dimana kantor sekarag hanya 6x6 meter dengan rincian 1 ruang direktur dan 1 ruang tamu, sehingga ketika ada ruang mediasi dan ruang negosiasi akan lebih baik, sehingga seluruh penyelesaian perkara bisa diselesaikan di LKBHI tanpa harus melalui proses litigasi. Selain aspek teknis secara sumberdaya manusia lembaga konsultasi bantuan hukum sedikit kesulitan untuk mengakses sumberdaya manusia dari perguruan tinggi umum, namun dengan adanya teknik yang unik dan amanah yang dilakukan oleh lembaga konsultasi dan bantuan hukum Islam IAIN Salatiga kedepannya menjadi motivasi calon penegak hukum baik yang berlatas belakan perguruan tinggi Islam maupun perguruan tinggi umum ${ }^{34}$

\section{Penutup}

Untuk menciptakan supremasi hukum yang berkeadilan, LKBHI IAIN Salatiga menjalankan prosedur hukum dengan focus terhadap pendidikan hukum guna menciptakan kesadaran dan budaya hukum masyarakat yang baik,

\footnotetext{
${ }^{32}$ Suyud Margono, ADR dan Arbitrase, Proses Pelembagaan dan Aspek. Hukum, Jakarta: Ghalia Indonesia, 2000), h. 5.

${ }^{33}$ Gary Goodpaster, Tinjauan Terbadap Penyelesaian Sengketa, artikel dalam Arbitrase di Indonesia, (Jakarta: Ghalia Indonesia,1995), h. 11.

${ }^{34}$ Wawancara dengan direktur LKBHI M. Yusuf Khummaini, 09-Januari-2019
} 
kemudian melakukan kajian atas problematika hukum yang ada di salatiga sekitarnya pada khususnya dan Indonesia pada umumnya, tidak terkecuali juga penyelesaian sengketa perkara perdata yang masuk ke dalam daftar penanganan perkara LKBHI IAIN Salatiga. Selain itu dengan dinamika hukum yang berkembang LKBHI IAIN Salatiga juga selalu mengembangkan sumber daya manusia guna menjawab tantangan global, dalam hal ini untuk menyelesaikan perkara hukum yang baik secara formal dan subtansial LKBHI IAIN Salatiga memilih negosiasi dan mediasi sebagai standar penyelesaian sengketa perdata di LKBHI IAIN Salatiga, sehingga cita hukum yang ada dapat terjawab dengan terciptanya penyelesaian sengketa berdasatkan win win solution, hal tersebut terlihat jelas dari hasil penelitian bahwa sejumlah 61 perkara perdata yang masuk di LKBHI IAIN Salatiga lebih banyak yang terselesaikan melalui proses negosiasi dan mediasi, sehingga menjadi cermin penyelesaian dan penegakan hukum di Indonesia bahwa sangat mungkin masalah perdata diselesaikan di luar pengadilan, dengan tujuan mampu menciptakan budaya penyelesaian sengketa melalui musyawarah dan terciptanya penyelesaian hukum yang efektif dan efisien, sehingga pembangunan hukum nasional tidak hanya menitik beratkan pada aspek kepastian hukum namun yang lebih ideal adalah membangun kepastian hukum yang berkeadilan.

\section{Daftar Pustaka}

Abdurahman, Aspek-aspek Bantuan Hukum di Indonesia, Jakarta: Cendana Press, 1983.

Dewi, Retno Sari dan Agustin, Viendha Yuli, Peran Lembaga Bantuan Hukum "Kartini" Dalam Menjamin Dan Memenubi Hak Rakyat Miskin Untuk Mendapatkan Akses Keadilan Di Dalam Proses Peradilan, Vol 3, No 12017.

Ginsberg, Morris, Keadilan Dalam Masyarakat, Bantul: Pondok Edukasi, 2003.

Gary, Goodpaster, Tinjauan Terbadap Penyelesaian Sengketa, artikel dalam Arbitrase di Indonesia, Jakarta: Ghalia Indonesia,1995.

Harahap, Yahya, Pembahasan dan Penerapan KUHAP: Penyidikan dan Penuntutan, Jakarta, Sinar Grafika, 2009.

Hariyanto, Peran LBH Kampus Di PTKIN Dalam Bantuan Hukum Terhadap Masyarakat Miskin, Jurnal Al-'Adl, Vol. 10 No. 1, Januari 2017.

Lubis, T. Mulya, Bantuan Hukum dan Kemiskinan Struktural, Jakarta: LP3ES, 1986.

Margono, Suyud, ADR dan Arbitrase, Proses Pelembagaan dan Aspek Hukum, Jakarta: Ghalia Indonesia, 2000.

Miller, Valerie dan Copey, Jane, Pedoman Advokasi: Kerangka kerja Untuk Perencanaan, Tindakan dan Refleksi, Jakarta: Yayasan Obor Indonesia, 2005. 
Muhammad, Abdul Kadir, Hukum Perdata Indonesia, Bandung: PT Citra Aditya Abadi, 2014.

Nasution, Adnan Buyung, Bantuan Hukum di Indonesia, Jakarta: LP3ES, 1988.

Rahardjo, Satjipto, Hukum dalam Perspektif Sejarah dan Perubahan Sosial dalam Pembangunan Hukum dalam Perspektif Politik. Hukum Nasional, Jakarta : Rajawali Press, 1996.

Reksodiputro, Mardjono, Sistem Peradilan Pidana Indonesia (Melihat Kejahatan dan Penegakan Hukum dalam Batas-Batas Toleransi), Jakarta: Pusat Keadilan dan Pengabdian Hukum, 1994

Saifudin, Yusuf, Implementasi Pemberian Bantuah Hukum bagi Rakyat Miskin di Jawa Tengah berdasarkan undang-undang nomor 16 tabun 2011 Tentang Bantuan Hukum, Jurnal Idea Hukum, Vol.1 Edisi Maret 2015.

Salamor, Yonna Beatrix, Pemberian Bantuan Hukum Kepada Masyarakat Miskin Di Kota Ambon, Vol. 2, No. 1, April 2018.

Soekanto, Soerjono, Pengantar Penelitian Hukum, Jakarta : UI Press, 1984.

Usman, Rahmadi, Pilihan Penyelesaian sengketa di Luar Pengadilan.

Winarta, Frans Hendra, Bantuan Hukum: Suatu Hak Asasi Manusia Bukan Belas Kasihan, Jakarta: PT Elex Media Komputindo, 2000.

BPHN, Ada Advokat dan Kampus Palsukan Data Demi Dana Bantuan Hukum. https://www.hukumonline.com

www.jurnal-unita.org/index.php/yustitia/article/download/131/123

UU No.18 Tahun 2003 Tentang Advokat

UU No.16 Tahun 2011 Tentang Bantuan Hukum

Perma No. 3 tahun 2012 tentang biaya proses penyelesaian perkara dan pengelolaannya pada mahkamah agung dan badan peradilan yang ada di bawahnya.

Perma No 1 tahun 2014 tentang pedoman pemberian layanan hukum bagi masyarakat tidak mampu.

Permenkumham RI No.1 Tahun 2018 pasal 1 tentang Paralegal Dalam Pemberian Bantuan Hukum. 
34 | Al-Istinbath: Jurnal Hukum Islam, Vol.4, No.1, 2019

HALAMAN SENGAJA DIKOSONGKAN 